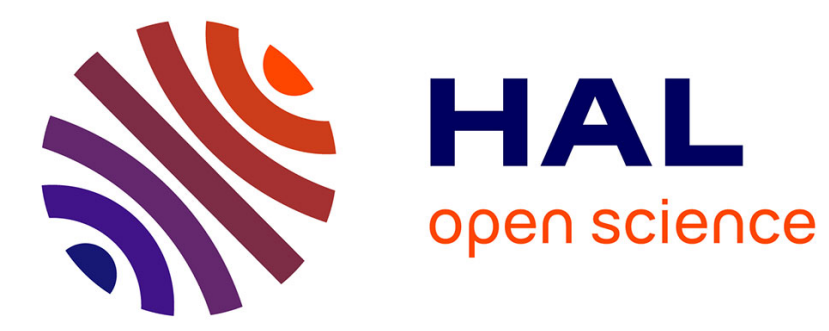

\title{
Lunacy and the 'Islands in the British Seas'
}

David Hirst

\section{To cite this version:}

David Hirst. Lunacy and the 'Islands in the British Seas'. History of Psychiatry, 2007, 18 (4), pp.411433. 10.1177/0957154X06075184 . hal-00570875

\section{HAL Id: hal-00570875 https://hal.science/hal-00570875}

Submitted on 1 Mar 2011

HAL is a multi-disciplinary open access archive for the deposit and dissemination of scientific research documents, whether they are published or not. The documents may come from teaching and research institutions in France or abroad, or from public or private research centers.
L'archive ouverte pluridisciplinaire HAL, est destinée au dépôt et à la diffusion de documents scientifiques de niveau recherche, publiés ou non, émanant des établissements d'enseignement et de recherche français ou étrangers, des laboratoires publics ou privés. 


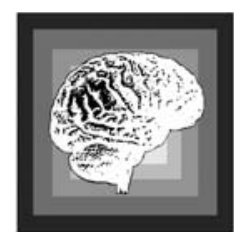

\title{
Lunacy and the 'Islands in the British Seas'
}

\author{
DAVID HIRST* \\ University of Bangor
}

\begin{abstract}
In the mid-nineteenth century the Dependent Territories of Fersey, Guernsey and the Isle of Man all had small, relatively stable populations, many of whom did not speak English as their first language. The response of each to the public asylum movement was very different. Guernsey had an asylum by 1852, but fersey and the Isle of Man opened permanent asylums only in 1868. This comparative study examines the interactions between British government agencies, the Home Office, Commissioners in Lunacy and Lieutenant Governors, and the autonomous insular legislatures. It discusses the reasons why fersey and the Isle of Man were reluctant to establish publicly funded asylums, the alternatives considered, and the opportunities afforded to private madhouse proprietors by absent or lax supervisory frameworks.
\end{abstract}

Keywords: asylum; Channel Islands; Commissioners in Lunacy; Dorothea Dix; Guernsey; history; Isle of Man; fersey; lunatic; 19th century

\section{Introduction}

The Isle of Man, and the Channel Islands of Guernsey and Jersey - the 'Islands in the British Seas' as they were collectively described in nineteenthcentury census reports - are all Crown Dependencies. Broadly speaking, this means they are not formally part of the United Kingdom and that domestic issues are determined by the respective island Parliaments: the Tynwald of the Isle of Man, the States of the Bailiwick of Jersey, and the States of Deliberation of the Bailiwick of Guernsey. Crown interests are represented by the respective Lieutenant Governors.

This devolution of powers has produced conflict and disagreement. The perceived status of the islands as 'tax havens' is currently a source of friction. The mid-nineteenth century revolution in government, which saw the

\footnotetext{
* Address for correspondence: School of Social Sciences, University of Bangor, College Road, Bangor, Gwynedd LL57 2DG, UK. Email: j.d.hirst@bangor.ac.uk
} 
expansion of centrally regulated welfare systems in the United Kingdom (see Stansky, 1973), created similar tensions. In practice, the social policies of the mainland were not directly applied to the Dependent Territories. Jersey retained a system of poor relief which relied on the parochial model, while in the Isle of Man there was no statutory system of poor relief prior to the Poor Relief Act, 1888, and the poor relied on voluntary contributions (Kermode, 2001: 26).

In the mid-nineteenth century the three Dependencies also had some economic and demographic similarities. They were relatively non-industrialized, with a high proportion of the population engaged in agriculture, fishing and some service industries. Many residents, particularly in the country districts, spoke Norman-French or Celtic languages rather than English as their first tongue. In 1871 the largest population, that of Jersey, was 56,627, smaller than any English county save Rutland. A high proportion of those aged 20 or over had been born locally, varying in 1871 from $80.35 \%$ in the Isle of Man to $59.42 \%$ in Jersey (see Table $1 ;$ p. 427).

These similarities did not include their responses to the problem of lunacy. In Guernsey, an asylum was in place by 1852 . The original plan had been to extend within the Town Hospital of St Peter Port. In both Jersey and Guernsey, the 'Hospital' was a multi-purpose institution,

partly a general Hospital for the sick, partly a workhouse and school for pauper children, partly a kind of prison for the dissolute and refractory of all classes and lastly the only receptacle for pauper lunatics, and without any resident medical man. (Public Record Office [hereafter PRO], HO45/6397, 1859)

Eventually, and largely fortuitously, a separate building was erected near the Town Hospital (Lenfestey, 1992). Holding 70, this was open to pauper lunatics from the town, and accommodated those from other Guernsey parishes for $12 / 6 \mathrm{~d}$. a week. Private patients were also taken (BPP, 1861: 179-81). The medical officer was non-resident, a local GP, succeeded in 1873 by his son-in-law (Carey 1938: 264).

The presence of this institution meant that neither the Lunacy Commissioners nor the Home Office were troubled by complaints about the condition of the lunatic population of Guernsey. This contrasts with both the Isle of Man and Jersey, where correspondence in the Public Record Office and elsewhere shows that the British authorities were constantly reminded of the absence of satisfactory institutional care. On both islands, permanent public asylums were opened only in 1868. In Jersey in particular, pressure for an alternative private sector solution was strong, and in both islands the resident Lieutenant Governors and the British government struggled to impose their preference. This paper explores the extension of the public asylum system to these Dependencies, and examines how the Home Office and Lunacy 
Commissioners sought to persuade the devolved insular administrations to accept a public asylum.

\section{Before the asylum: community care}

In both Jersey and the Isle of Man there were relatively stable populations with extended kinship links to provide support. The rural and remote nature of the islands, and the parochially based or non-existent local welfare systems, meant most of the mentally ill remained with relatives. Those deemed to be dangerous or unmanageable were confined in sheds or outhouses. This situation met with the acceptance or at least acquiescence of local landowners, the secular and ecclesiastical authorities of local parishes, and many local professionals. Not until lunatics were discovered by agents of the modernizing world outside was pressure placed on the agencies of the central government in London to intervene.

In Jersey, Jane Le Maistre's 'confinement was known to every person in the Parish of St Ouen' for upwards of 20 years (Jersey Archives [hereafter JA], ACTES, 1846a) but no action was taken until she was noticed by an English cattle dealer who called at the farm where she was held. He told J. C. Royston, an English solicitor living in St Helier. Having 'chosen a market day as being most likely the Proprietor of the premises would be at market', Royston visited the area with a friend, but found the farm elusive, for 'as strangers, [we had] some difficulty in making ourselves understood, as there seemed so very few who understood the English language' (JA, ACTES, 1846b). Eventually the two men found Jane Le Maistre. She was:

confined in an out-building ... without any clothing on her person ... except a coarse woollen cloth thrown over her. ... she appeared to sit in the attitude of a monkey, and [we were] informed that she had been in that position for so long, that the limbs in the lower part of her body were motionless. (JA, ACTES, 1846c)

Royston raised the case with Jersey's Attorney General and Lieutenant Governor (JA, ACTES, 1846b). Theoretically, someone suffering from mental illness such as Le Maistre should have been placed under the care of a Curateur, but these legal processes were often dispensed with (BPP, 1861: 614-22). Once the Le Maistre case became a public issue, the Royal Court was quickly convened, but the local inhabitants responded defensively, claiming she was well cared for, being 'cleaned several times a day' (JA, ACTES, 1846d). They were supported by local professionals. Two doctors, whose visit had clearly been anticipated, found Jane Le Maistre:

wrapped in two warm blankets; her person was clean, her hair short, and there was no appearance of any filth or vermin - A pot-de-chambre lay near her, in which, they told us, she is in the habit of relieving herself 
and which is daily removed by her attendants ... her nails were the usual length, she was in good condition but made no attempt to use her lower limbs, which as we were told by her brother, lost their power before her mind was affected.

They questioned whether an asylum would help such long-standing cases (JA, ACTES, 1847).

This was not untypical of local medical opinion. A neighbour of another Jersey lunatic was Dr Lowe, a GP and, later, Deputy (elected representative in the States Parliament) for St Brelades. Some twelve years later, he had no concerns about the confinement in an outhouse of the neighbouring lunatic, locked away after attacking him. Dr Lowe then thought an asylum would cost too much, especially as the island was 'very much in debt' (BPP, 1861: 635-9).

The Hospital Committee of the States Parliament thus concluded a lunatic asylum was not required. It cited the cost, especially as it was expected that only fifty or fewer cases needed confinement. The numbers meant that if 'a classification of those persons was tried, it would lead, so to speak, to isolation, and isolation, in most cases of lunacy, would only increase it.' The Committee cited Dr John Conolly's view that 'an asylum ... of any number above 100, is more easily managed, and with better effect upon the patients, and more comfortably and cheerfully for them, than the smaller asylums.' Finally:

having interrogated their relations, [the Committee] has found with them the most marked repugnance to be separated from those unfortunates; they are persuaded that nowhere will they receive the same care as at their own house, and are consequently strongly opposed to their being placed in a public establishment. (JA, A/J/7, 1847)

For those lunatics who had no previous connection with the island, or whose family were dead, unwilling or unable to care, only the Hospital was available. In 1847 the Hospital housed 38 lunatics and idiots (JA, A/J/7, 1847), and by 1852, 14 dangerous and 13 harmless lunatics together with 9 idiots capable of working and 10 'useless' (JA, ACTES, 1852).

As an alternative to a specialized asylum, the Hospital Committee recommended adaptations to the existing institution, building some cells in 'part of the small garden', a plan subsequently abandoned as being too confined a space (BPP, 1861:30-3). It called for power to transfer lunatics who were unsuitable for detention in the Hospital 'or when there should be reason to believe that a special treatment in an asylum for lunatics might lead to his recovery' to asylums in France or England, and to 'forbid, under severe penalties, the shutting up of a lunatic without informing the constable and Committee of the States' (JA, A/J/7, 1847).

Six years later the Hospital Committee returned to the subject, asking two resident doctors to prepare reports. One, Dr de Caux, who 'never before had 
studied lunacy, and scarcely knew the modern system at all', suggested the conversion of a farm into an institution (Houghton Library [hereafter HL], $1855 b$; JA, ACTES, 1853). The other, Dr D. H. van Leeuwen, a Dutchman who had moved to Jersey, had already drawn attention to the problems through a series of exposes in the Jersey Chronique (Gollaher, 1993: 359; HL, 1855b). His report was an extensive review of asylum provision on the continent, and supported the erection of a new institution (van Leeuwen, 1853). No action followed.

Care by relatives was also the norm in the Isle of Man, a problem exacerbated by the lack of poor law provision. In 1855 one local paper commented:

Almost every parish has its crazed people, and some have ten or more. Many of them are chained up in dark, filthy and solitary cells; others are locked in miserable garrets, whereby by starvation and cruelty their first slight aberration of mind is converted into confirmed and incurable madness. Indeed, the places selected for these crushed and miserable ones, and the treatment they receive, would inevitably drive sane persons mad, however curable they might be before. (Mona's Herald [hereafter $M H], 1855 b$ )

As with Jersey, they were largely ignored until 'discovery' took place by an outsider, although their existence and the conditions in which they were kept were clearly known to many in authority. One visitor was told by the Governor of Castle Rushen 'that within a few miles of Castletown a lunatic was confined in a room, his food being given to him through a window' (Manx National Heritage Library [hereafter MNHL], 9845/1/9, 1861b).

Without any public infrastructure to maintain the poor, some lunatics wandered freely: 'If we walk the streets of our towns, or travel on the highways of the country, we ever and anon meet with idiots, lunatics and raving madmen and women who require supervision and safekeeping' $(M H, 1855 a)$. An alternative solution was export:

[P] auper lunatics found on these shores, be they English, Irish, Scotch or Manx, who have no friends here with the grace of God in them, are shipped off to Liverpool, put down in the streets and left to wander there till picked up by a policeman, or caused to starve to death beside some hovel in the suburbs, or be 'found drowned' in a pond or ditch. Such are the tender mercies toward suffering humanity displayed here in more than one of our towns! The wretched people concerned in it club together and raise a few shillings for the skipper of the lugger to do the transportation neatly and slily $[s i c] .(M H, 1855 b)$

In 1863, the Lieutenant Governor wrote to local officials that:

A rumour having reached me that it has occasionally been the practice for families who have the misfortune to have a lunatic person as one of 
its numbers, to treat such lunatic with great severity, and that in some instances they have been confined in outhouses, bound with chains or ropes, and otherwise subjected to great ill usage, I beg that you will report to me on this subject and that you will loose [sic] no time in making the most diligent inquiries through your Parish as to whether there are any Lunatics at present subjected to this treatment. (MNHL, GO61/40, 1863)

Although one or two responses mentioned historic cases, all denied that any lunatics were currently being held in inhumane conditions (MNHL, GO61/100, 1863-64). It was thus unfortunate that a matter of months later both the local press and The Times carried an account of a lunatic called Waterson, from the hamlet of Ballykilloway, between Castletown and Port Erin, who 'was frightened out of his wits by an apprentice who appeared before him in a white sheet'. He had never recovered, and had been confined in:

a filthy outhouse, the walls damp and unsightly, the cold clay floor not even strewn with clean straw, the morsel there is both old and damp. Barred in, almost excluded from the light, unseen save by some curious visitor, untended, his food lowered down to him, here in this terrible prison he has existed for 17 years. ( $M H, 1864 a$; The Times, 1864)

To some extent, both insular governments had restricted options due to the policy of the British Government opposing the transfer of patients off island. In Jersey the States had first voted to send patients to asylums in France or England in 1839 (JA, C/A5/3, 1839b). This was referred by the Lieutenant Governor to the Home Office, who were:

of opinion that no British subject ought to be confined in a lunatic asylum beyond the control of British authority, and that therefore, the Act of the States of Jersey, making it legal to send persons afflicted with mental derangement to a Lunatic asylum in France, ought not to be confirmed. (JA, A/J/7, 1839)

The Lieutenant-Governor therefore vetoed the proposal (JA, C/A5/3, $1839 a$ ).

The possibility of sending patients to England was largely ignored in this discussion, but this may have been a reflection of the likely outcome of the States' intention. The Norman-French language of the majority of the native population and the close proximity of the French regions of Normandy and Brittany would mean the majority of patients being sent to France. There is certainly evidence that, nearly forty years later, some of those housed in the Jersey Asylum were 'sent over from France', presumably as returnees to the island (JA, Jersey Asylum, 1869).

In the Isle of Man the same problem initially elicited a different response. In 1845 the Lieutenant Governor was able to persuade the Home Office to agree to the transfer of two criminal lunatics to the Haydock Lodge asylum at Newton-le-Willows, between Liverpool and Manchester, England (MNHL, 
$9845 / 1 / 4,1845)$. Other criminal lunatics followed. They remained in Haydock Lodge throughout the controversy which erupted in 1846 (see Hirst, 2005; Parry-Jones, 1972), but after February 1847 subsequent cases were sent elsewhere, principally to the Crichton Royal Institution, Dumfries, Scotland (MNHL, 9845/1/5, 1847a; 1847b). Later in 1847, however, the Home Office reversed its stance and asked the Lieutenant Governor to 'consult the Attorney General in the Isle of Man for the purpose of ascertaining whether there are any legal obstacles in the way' of sending lunatics to the mainland (MNHL, 9845/1/5, 1847c). The island's Attorney General confirmed that legal authority for the removal of criminal lunatics to the mainland did not exist (MNHL, 9845/1/5, 1847d). Subsequent attempts by the Lieutenant Governor to persuade the Home Office to allow the transfer of criminal lunatics to the mainland were unsuccessful (MNHL, 9845/1/6, 1850a; 1850b). All newly detained criminal lunatics were now held in the only prison on the island, the medieval fortress of Castle Rushen, though the principle that their costs were met by the Home Office remained.

That this principle did not apply in Jersey is shown by the case of Joshué Le Gresley, a criminal lunatic with a history of alcohol abuse and mental illness confined for killing his wife (The Times, 1856). In this instance, the Royal Court had properly convened and appointed a relative, Charles Blampied, as Curateur. Blampied was reluctant to undertake the role, and petitioned for Le Gresley to be treated in an asylum in England (JA, A/A1/10, 1857). His prime concern seems to have been the position of Le Gresley's three children - as was later confirmed by the Jersey law officers:

It is apparent that the whole of the small income of Le Gresley, which arises I understand from the rent of some land, will be devoted to his maintenance while under restraint, and that of his family will fall upon their Parish. Thus the States escape all expense for the subsistence of a criminal imprisoned by sentence of the Royal Court of this island, and of one who, it is but too probable, will be in confinement for life. (PRO, $\mathrm{HO} 45 / 6397,1857 a$ )

\section{Voluntary or private alternatives to a public asylum}

In responding to both the periodic public concern and increasing administrative difficulties caused by the lack of asylum accommodation, the Home Office and Lunacy Commissioners, and the British representatives on the islands, had to co-operate with a devolved political structure. Unlike counties in England and Wales, the preferences of the British Government could only be implemented with the consent of the insular legislature.

On the Isle of Man, moreover, neither poor law nor general local taxation existed. Public works were paid for from the 'surplus revenues' associated with customs and excise duties. The lack of powers to raise local revenue restricted the actions of the Lieutenant Governor and the Tynwald, the 
bicameral legislature of the island. Consequently, when the Tynwald in 1849 passed legislation permitting criminal lunatics to be held in custody, the Act envisaged an asylum paid for by voluntary subscriptions (Statutes, 2: 257). The Lieutenant Governor thought the House of Keys (the lower, representative house of the Tynwald) would not agree to levy taxes, either to pay the costs of an asylum or for the maintenance of the lunatics. He suggested the United Kingdom Treasury give a grant of $50 \%$ of the cost of the asylum as an incentive to subscribers (MNHL, 9845/1/6, 1850c). To this the Treasury agreed (MNHL, 9845/1/6, 1850d).

In April the following year the Lieutenant Governor circulated a printed appeal for funds to build an asylum 'for about thirty patients as Paupers and Criminal Lunatics who may be placed there by the Government' together with a few paying patients. The initial subscribers were members of the Lieutenant Governor's Council, the upper chamber of the Tynwald, together with seventeen members of the Keys (MNHL, 4133C).

This proposal did not receive universal approval, and it became a proxy for other grievances. In some areas and parishes, there were no subscribers to the asylum (MNHL, 4142C; 4155C). At a meeting in Douglas opponents argued that as the British government was receiving customs revenues from the Isle of Man, these 'surplus revenues' should be used to pay for an asylum $(\mathrm{MH}, 1851)$. The proposed site was Rushen Abbey, bought by two individuals who hoped to use it for charitable purposes (MNHL, 4153C; 4151/2C). However, part of the Abbey building was already on a long-term lease to a girls' boarding school (MNHL, 4146C). Only $£ 1100$ in subscriptions was pledged, not enough to build an asylum (MNHL, 4139C). Worse was to follow:

$[\mathrm{O}]$ nly a portion of these subscriptions were paid, and unfortunately they were paid into a Bank which failed before any provision could be made for disposing of the money, \& I fear but a small amount will now be recovered. (MNHL, 9845/1/8, 1858a)

No serious consideration seems to have been given in the Isle of Man to using a private madhouse. A friend of the Bishop was 'most anxious to promote a lunatic asylum in the Isle of Man', leading him to ask the Lieutenant Governor, without success, to 'hold off your plan' for a subscription asylum (MNHL, 4151/1C). Later, a madhouse proprietor whose licence had been revoked moved there, with his patients. As the Commissioners in Lunacy noted, their regulatory powers did not extend to the islands, and this loophole could be exploited:

[D] elinquent proprietors of licensed Houses in England have already twice treated our threats of revocation of their license with contempt, and have fled with their patients beyond our reach, in the one case to Jersey, and in the other to the Isle of Man. (BPP, 1862) 
In the case of the Manx fugitive, nothing further is known - he does not appear to have come to the notice of the Lieutenant Governor, Tynwald, or the local press. In Jersey, however, the consequences were both longer lasting and more serious.

Grove Place in Hampshire, England, was a failing institution, repeatedly criticized in the Reports of the Commissioners in Lunacy (BPP 1854; 1854-55; 1856). In June 1854 its Medical Officer had resigned due to nonpayment of salary (PRO, MH50/7, 1854a). Isaac Pothecary, the proprietor, was declared bankrupt (The Times, 1854) and subsequently imprisoned in the county gaol for contempt of the Court of Chancery (PRO, MH50/7, $1854 b$ ). The licence was then revoked (PRO, MH 50/7, 1855b). Pothecary's response, once free, was to 'transport not less than 20 patients private, some paid [i.e., paying] $£ 500$ or more per annum to Jersey where no License is required' (HL, 1855a). The Commissioners in Lunacy, who discovered his proposed move from a letter he had sent to the sister of one patient, were powerless to intervene (PRO, MH50/7, 1855a).

Once on the island, Pothecary invited Dr van Leeuwen to be visiting physician, and to 'to look for two or more fit places for their [the patients] reception'. Although aware of Pothecary's background, van Leeuwen accepted, thinking this would be the lesser of two evils: 'I therefore have not refused my medical aid, but will first see them come, then observe and then decide whether my fears of Mr Pothecary will be justified, \& whether I may or ought not, tender my services to his asylum' (HL, 1855a). By July, he had fallen out with Pothecary who refused to pay van Leeuwen's cab fares to the asylum (HL, 1855d).

By coincidence, van Leeuwen was then in contact with Daniel Hack Tuke, youngest son of Samuel Tuke, founder of the York Retreat (on the Retreat, see Digby, 1985). The celebrated American campaigner for the mentally ill, Dorothea Dix, was then staying with Tuke, not in good health. To occupy her, he had given her some reading, including some of van Leeuwen's articles. After reading these, she asked Tuke to contact van Leeuwen for more information (Gollaher, 1993: 358; Wilson, 1975: 229). Van Leeuwen now appealed to Dix for support.

Once recovered, Dix went to Jersey in July 1855 . During a three-week stay she visited Pothecary's newly arrived lunatics, giving him 'the blackest character' (Fersey Independent [hereafter FI], 1861f). She saw some of the indigenous insane, both those in the community and those in the Hospital, where she found 40 lunatics 'in a horrid state, naked, filthy and attended by persons of ill character' (Gollaher, 1993: 361). Armed with a letter of introduction from Sir George Grey, the Home Secretary (HL, 1855c), she persuaded the States of Jersey, 'the governing body of the Channel Islands [sic]' to agree to an asylum costing $£ 10,000$ to $£ 12,000$, and had Pothecary arrested for a breach of the island's regulations (Wilson, 1975: 233). 
In practice, there was no effective action. Van Leeuwen had warned that the States Parliament was 'a very demoralised and inert body; their president, the Bailiff, Sir Le Breton [sic], is idiotic by age; the most energetic member of the States, who leads everything [Francois Godfray], is a man of no progress whatsoever.' (HL, 1855b). Presciently, he also predicted the likely outcome:

They will either promise much and do nothing, or name again a subcommittee for looking for suitable grounds ... Or, and I would not be surprised at this, the States of Jersey will agree with Mr Pothecary; who has now settled himself in Jersey, and already imported a few rich lunatics from England; and the pauper insane will be boarded in his establishment at one [shilling and] 6 pence per day, like they are now in the general Hospital. (HL, 1855b)

Following Dix's visit, the Hospital Committee of the States did issue a report incorporating some of her suggestions and proposing a public asylum for 100 patients at an estimated cost of $£ 10,000$. The Committee also proposed that private asylums should not be permitted, as the independent supervision available in England was not available (JA, ACTES, 1855). Even van Leeuwen thought the report 'good in many respects', although he had 'been consulted in nothing' (HL, 1855e). The report did not proceed further. Two years after Dix's visit the Lieutenant Governor made a reference to it in a letter to the Home Office:

In order, moreover, to prove how entirely alive to the subject of the proper custody of Lunatics the island authorities have been for some time past I have the honour to enclose a printed copy of a Report of a previous Committee, dated $19^{\text {th }}$ September 1855 , and 'loge au Greffe' [a stage in the legislative process] two days later, whence it has not since been dislodged. (PRO, HO45/6397, 1857b)

Pothecary was soon released to begin operating his asylum. Up to 27 patients were cared for at any one time, and Pothecary turned others away. In 1858 he leased 'a house and lands situate in one of the healthiest parts of the island'. Now claiming to have been 'for many years, the proprietor and manager of a Lunatic Asylum, licenced according to Act of Parliament, and [who has] obtained many favourable reports from the [Lunacy] Commissioners and Magistrates' he suggested that he should:

take under his care, the pauper patients of this Island, as is done in England, in towns or places where there is no Public Asylum, and that he would do so at reasonable charges and conditions and submit to such regulations and superintendence as [the States] might think proper ... (JA, ACTES, 1858) 
The 'house and lands', later to be sold to him, was Bagatelle, a short distance outside the capital, St Helier. The property was a 'long rectangular four storey house, with twelve rooms and four attics, plus offices, etc., ... There was a Regency iron balcony, with a curved zinc covered roof on the front elevation' (Croad, 1981: 67). Perhaps more significantly, the house had been sold by Francois Godfray, at this time, the leader of the dominant Laurel, or traditionalist party in the States Parliament. Godfray was a man of great influence, a passionate, irascible, forceful speaker: 'With whirling arms and voice of thunder he beat down all opposition. No such oratory had been heard in Jersey for generations' (Balleine, 1948: 291). He was, however, in financial difficulties after the failure of many property speculations (Croad, 1981: 70). After the sale of Bagatelle, Godfray became the champion of Pothecary on Jersey.

In April 1859 the Hospital Committee voted to place pauper lunatics with Pothecary, ostensibly while a public asylum was built. The vote was unanimous, though motives were mixed. Some saw this as a way of removing lunatics in the hospital until the erection of a public asylum, but others wanted to foil these plans by passing the care of island lunatics to the private market on a permanent basis $(\mathrm{JA}, \mathrm{A} / \mathrm{J} / 7,1859 ; \mathcal{F I}, 1861 f)$. The Home Office and the Commissioners in Lunacy immediately objected that Pothecary was not a fit person to be in charge of lunatics (PRO, HO 45/7130, 1859), and the planned transfer was suspended.

In April 1860 the States, in a gesture towards the regulatory framework of the mainland, passed regulations for the supervision of lunatic asylums (JA, ACTES, 1860a; A/J/7, 1860a). A Committee was 'to have the supervision of lunatic asylums, and to see that lunatics who live with their families are treated in a proper manner' (JA, A/J/7, 1860a). Almost simultaneously, the States re-affirmed its decision to erect a public asylum, and invited landowners to tender land 'to the extent of thirty vergees [approx. 7.5 acres or 3 hectares] or thereabouts' on which the asylum could be erected (JA, A/J/7, 1860b).

A month after the Act was passed, Pothecary applied for a licence for 90 patients, split equally between males and females (JA, ACTES, 1860b). After a visit to Bagatelle, the committee allowed a licence for 50 patients, 30 males in the house itself, and 20 females in the adjoining buildings (JA, ACTES, $1860 c ; \mathcal{F I}, 1861 a$ ). Pothecary then approached the States again, now offering to sell Bagatelle to them. Alternatively, he would sell 'Thirty vergees of land and the buildings I have erected for pauper lunatics' or fulfil the contract previously entered into (JA, ACTES, 1860d). From this, it is evident that Pothecary had prepared Bagatelle in the expectation that pauper lunatics - from Jersey or elsewhere - would be among the residents, and now feared that a public asylum might yet be built. The decision on a site for a 
public asylum was repeatedly delayed, though this may be a reflection of the desire of many influential members of the States to make an agreement with Pothecary (JA, A/J/7, 1861a).

At this point, conflict between the States and the Lieutenant Governor intensified. In March 1861 the Lieutenant Governor offered the States up to $£ 5000$ towards the cost of the public asylum when the site had been secured (JA, A/A1/11, 1861). Later that month, the Lieutenant Governor personally visited a site owned by the British Government called Queen's Farm which he thought 'would be admirably suited for the purpose' (JA, C/A5/3, 1861). The States continued to prevaricate. By May 1861 the Lieutenant Governor could 'perceive no immediate prospect of a speedy fulfilment' of the promise to build a public asylum. Despite the offer of part funding, and of a site, 'prolonged and vexatious delays have occurred' (JA, A/A1/11, 1861).

The States meanwhile continued to press for a private solution. In March 1861 Francois Godfray proposed that they place the lunatics into the care of Pothecary for three years. The main argument was that 'the public revenues, which are greatly burdened with debt, do not permit for the present the incurring of the great expense which the establishment of a lunatic asylum would require'. Additionally, Godfray argued that the total numbers of lunatics did not justify the overall expenditure of a public asylum:

[T] he States, having granted a licence to Mr Isaac Pothecary to keep an asylum of this kind, ... the insane now in the General Hospital, who do not exceed 40 in number, can be placed there, where they will be properly kept and attended to at a cost of $£ 1000$ sterling per annum. ( JA, A/J/7, 1861b)

Although the proposal was to make a three-year arrangement with Pothecary, this was effectively a motion to hand over the island's lunatics to him permanently. The resolution also called for a twelve-month moratorium on the selection of a site for the public asylum, as Godfray asserted that it would be useless to discuss opening one if his motion was adopted ( $F I, 1861 a$ ). The adoption of Godfray's motion by the States precipitated open conflict between the Island politicians and the Lieutenant Governor, who exercised his right to veto States legislation (JA, ACTES, 1861a). In a letter to the Home Office he explained that Pothecary was unsuitable, and was not being asked for financial guarantees, necessary as 'it is a well known fact that $\mathrm{Mr}$ Pothecary is in such embarrassed circumstances that no confidence can be entertained as to his being enabled to maintain his establishment for lunatics for so long a period as three years'. Moreover the States had previously made a clear commitment to build a public asylum (JA, ACTES, 1861b). The States demonstrated its intransigence by wrangling over the lease of Queens Farm - claiming it was worth only $£ 70$ per year rather than the $£ 80$ required by the British Government $(\mathcal{F} I, 1861 b)$. 
The States determined to challenge the Governor's veto at the Privy Council ( $F I, 1861 c)$. An attempt to compromise with the Lieutenant Governor prompted an even more impassioned and vituperative debate, and was eventually defeated on the casting vote of the Bailiff (the Presiding Officer and a Government appointee). Although personally opposed to the plan, the Bailiff felt compelled to follow precedent and vote to allow the matter to proceed $(\mathcal{F}, 1861 f)$. The Lieutenant Governor discussed with British government law officers whether he would be justified in vetoing the proposed legal action against himself (PRO, HO45/7130, 1862; PC 8/22, 1862).

The background to this confrontation is complex. The fortunes of Francois Godfray and Isaac Pothecary, neither of whom was in good financial health, had become intertwined in the lease and sale of Bagatelle as a lunatic asylum. Godfray saw no conflict of interest: 'It has been insinuated - insinuations are cowardly weapons - that he had an interest in sustaining Mr Pothecary. It was a great calumny; whether Mr Pothecary prospered or not was a matter of indifference to him ( $F I, 1861 e)$.' Godfray's position as leader of the Laurel party in the States gave him considerable influence. Beyond this, other supporters of the private alternative were prepared to advance a variety of arguments based on the flimsiest of foundations. One thought private asylum proprietors were being persecuted by the Lunacy Commissioners because their asylums 'interfered with the success of the county establishment owing to their being better managed' ( $I I, 1861 a)$. Another relied on Dr Wynter's Curiosities of Civilisation:

In England lunatics were placed in private asylums in preference to the best public asylum ... in private asylums the percentage of cures was from 62 to 72 per cent, while in the best public asylums it did not exceed 15 per cent. (Anon., 1861)

Wider political issues also intruded. For some years Abraham Le Cras, a prolific political pamphleteer, had argued that the sovereignty of the States over island affairs was 'founded on fraud and usurpation'. Le Cras had succeeded in persuading the British government to establish Royal Commissions examining the criminal and civil laws of the island, as an ultimately unsuccessful platform from which to attack both the conduct and the legitimacy of insular institutions (Balleine, 1948: 385ff; BPP, 1847; 1861). For conservative devolutionists such as Godfray, this was an affront, and the opportunity to state their case by challenging the Lieutenant Governor's right to interfere in the legislative process represented too good an opportunity to let pass.

The decision to challenge the Lieutenant Governor's veto was, however, opposed by a coalition of interests. The first group was the minority in the States Assembly. This 'numbered some of the most important members of the assembly, including the Bailiff, the Dean, Magistrate of the Police Court, 
Attorney General, Solicitor General and the majority of the Rectors'; the motion was carried only with the support of the majority of Constables and Deputies $(\mathcal{I} I, 1861 d)$. This hints at a broad division between elected followers of the Laurel party, on the one hand, and Crown and other appointees, together with followers of the Rose Party, on the other. Their objections were both constitutional and humanist, believing the lunatics were better placed in a public asylum.

Secondly, the policy was opposed by those challenging what they saw as the corruption and inactivity of the States assembly. Prominent here were two individuals who had written to the Lunacy Commissioners about Joshué Le Gresley: Grantham Dodd and G. Julien Harney. Dodd, an English solicitor (i.e., not licensed to practise in Jersey), had experienced the more bizarre side of the autonomous Jersey legal system, having been falsely imprisoned for three years as a debtor after a dispute over a deed of trust. In the process, he had had ample opportunity to study the treatment of Le Gresley and other lunatics kept alongside him (BPP, 1861: 89-100; Kelleher, 1991: 334-8). Harney was a former leader of the Chartist movement who was by then Editor of the fersey Independent (Goodway, 2004).

The third group were the followers of Abraham Le Cras, particularly the 'half pay colonels' and other British residents who disliked the variation from the political structures of conservative English towns. Under the guise of the 'Jersey Constitutional Reform Association', this group massed to oppose the decision to pursue a Privy Council case. At a public meeting on 9 November 1861, where 'some hundreds were unable to obtain admission', the opposition to the majority in the States gave voice to its feelings ( $\mathcal{I}$, $1861 \mathrm{~g}$ ). For this group, the potential legal costs of up to $£ 2-3000$ reinforced their opposition to anything which might reinforce the case for independence from the Crown. The reciprocal loathing between the parties can be gauged by Godfray's subsequent proposal that the Chairman of the meeting be prosecuted 'for sending an insulting motion to the States' (FI, 1861h). The Lieutenant Governor, however, took a different view, believing the resolutions represented 'the sentiments of a most influential portion, and, as I believe, the majority of the electors of Jersey' (FI, 1861i).

\section{State asylums arrive}

Despite the opposition, the case proceeded to a full hearing before the Privy Council (JA, A/J/7, 1862). The judgment was, however, unfavourable to the States (Moore, 1867, Vol. 15: 195-208; JA, ACTES, 1862a). Opposition to a publicly funded asylum then collapsed. In December 1862 the Asylum Committee approached the Lieutenant Governor asking for the release of the Queen's Farm monies (JA, ACTES, 1862b). Negotiations did not go smoothly, and matters were not resolved until May 1863 (JA, ACTES, 1863a). By September 1863 the Committee had received a report from 
Dr Boyd, Superintendent of the Somerset Asylum, suggesting an asylum for 60 patients, 30 of each sex (JA, ACTES, 1863b). Even at this stage, financial issues intruded, as the Treasury objected to the use of fines (surplus revenue) to help to pay for the asylum. Accidentally or otherwise, the Lieutenant Governor seems to have ignored this letter until the asylum was a fait accompli (PRO, HO45/7130, 1863). Perhaps as an inevitable consequence of the choice of a public asylum, Isaac Pothecary was declared 'en décret' (bankrupt) in November 1865 (JA, D/Y/F3/49, 1865). This did not end his career as an asylum proprietor, however. The asylum at Bagatelle seems to have continued until, in February 1866, Pothecary applied for, and was granted, a licence for a smaller asylum for 30 of his private patients at Cranbourn Hall in the Parish of Grouville (JA, C/C/W2/1, 1866). He ran this establishment until January 1880 when he was bought out by Dr George Moore, who later became Superintendent of the Jersey Lunatic Asylum (JA, C/C/W2/1, 1880).

After some years' building, the Jersey Asylum opened in July 1868, with 26 patients being admitted. By December 1869, when the first Annual Report was issued, the numbers had grown to 46, with 21 males and 25 females (JA, Jersey Asylum, 1869).

On the Isle of Man, the most pressing problems were caused by the accumulation of criminal lunatics in the prison at Castle Rushen. This had to cater for three groups - debtors, ordinary criminals and criminal lunatics, of both sexes - and complete segregation was impossible. The male lunatics had to mix with the ordinary prisoners, unless labour and outdoor exercise for one class of prisoner was forbidden. Female lunatics could be kept in a few rooms in the upper part of the building, but only because no female debtors were then imprisoned (MNHL, GO61/23, 1864). For one visitor, the arrangements 'expose unfortunate and defenceless debtors to the ruthless violence - the bloody-knife and the murderous stone-hammer of the frenzied and unfortunate madman' $(M H, 1855 b)$. Another felt 'confinement with the insane, must be a serious addition to the punishment of the criminal' (MNHL, 9845/1/8 1858c). As Dr John Henry Wilson of Liverpool pointed out, using Castle Rushen deterred relatives: 'There can be no doubt that, many of whom nothing is heard are kept in close confinement by their friends for fear of being sent to Castle Rushen to be associated with felons.' He emphasized the problem of staffing; there had been no increase in staff 'since they have received insane prisoners who were formerly shipped off to some English Port' (MNHL, 9845/1/9, 1861b). In December 1863 there was only one Matron for 12 women, 4 of whom were lunatic. 'The Lunatics are therefore often necessarily left in [the] charge of the other prisoners' (MNHL, 9845/1/10, 1863b).

In 1858 the Manx authorities had been urged by the Home Office 'to entertain the question of providing a suitable Asylum without delay, and ... for that purpose pass an Act of Tynwald to authorize the raising of the necessary sum by Rate or otherwise' (MNHL, 9845/1/8, 1858b). The Lieutenant 
Governor responded that a Bill would be placed before the House of Keys. The Tynwald eventually consented to the Act in 1860 (Statutes, 3: 49). It contained a clause allowing a land valuation for rating purposes to pay the island's share of the cost, but also allowed lunatics to be kept by relatives, if they were receiving proper care.

Detailed and protracted negotiations between the island and the British authorities continued both during the passage of the Act and afterwards (see BPP, 1864). These were only a part of developing discussions prompted by other financial and legal issues which focussed attention on the constitutional and representative arrangements of the island (for a general discussion, see Belchem, 2000: 18-94, esp. 58-72). Action was slow to follow. In August 1861 the land valuation had not started due to a 'delay in finding competent valuers' (MNHL, 9845/1/9, 1861a). After some searching, a site for an asylum was identified at Strang, near Douglas $(M H, 1862)$. In November 1863 the Keys acknowledged the misery caused by 'want of proper asylum for the reception of non-criminal lunatics' $(M H, 1863)$, and the island's Law Officers debated whether non-criminal lunatics could be confined in Castle Rushen (MNHL, 9845/1/10, 1863a). In 1864 the Keys approved an Act for a temporary asylum until the permanent structure could be built (Statutes 3: 109). Various possibilities, including the 'herring houses' (fish processing sheds) at Derby Haven (MNHL, GO61/57, 1864) were examined before a house called Oatlands was finally secured (MNHL, 9845/1/10, 1864b).

As work progressed on the rating of property to pay for the institution, opposition, which had been muted during the passing of the original legislation, became more vocal. Motives were mixed. In part the opposition was financial, arguing either that the central government should pay all the cost out of the surplus revenues, or that the building was too large $(M H, 1864 d)$. The Lieutenant Governor suggested omitting the chapel to reduce costs, despite the almost universal presence of a dedicated chapel in Victorian public asylums (MNHL, 9845/1/10, 1864a; Taylor, 1991). Again, wider political issues intruded. Some prospective ratepayers felt disenfranchised by the method of appointing the House of Keys and wanted a more democratic system of government for the island (PRO, HO45/6570, 1864). (Not until 1867 was the membership directly elected on a restricted franchise; Belchem, 2000: 82-4.)

The opposition attempted to exert its influence both on the Island and on the mainland. It had some temporary success when, following a petition, the House of Commons voted to reject the $50 \%$ grant to the island, on the grounds that, as with the county councils, it should raise its own revenue ( $M H, 1864 c$; MNHL, GO61/60, 1864; Parl. Deb., 1864). This was subsequently reversed, though not without opposition (Parl. Deb., 1865).

As with Jersey, opponents questioned how many lunatics needed accommodation. Kirk Bride parish declared 'there has not belonged in this parish for the last three hundred years a single lunatic that required protection, restraint or 
support from the parish' ( $M H, 1864 e$; original emphasis), and other parishes, particularly in the more rural north, also opposed a large building. Against such polemic the island's establishment deployed calculations based on the percentage of lunatics on the mainland $(M H, 1864 b)$.

The temporary asylum, 'an ordinary dwelling house' $(M H, 1865 a)$, opened in late 1864 . The first statistics revealed 10 criminal lunatics ( 7 men and 3 women) and 15 pauper lunatics ( 7 men and 8 women) (MNHL, GO61/19, 1865). Three months later, a new survey showed 135 lunatics on the island, of which ' 42 have been returned as properly cared for by their friends; but most of this number their friends are very anxious to send to the permanent asylum when it is completed.' Kirk Bride had a proportionately larger number of lunatics than any other parish $(M H, 1865 \mathrm{~b})$. The temporary asylum was deemed too small, and in response the Keys passed an Act to extend it (Statutes 3: 329). In June 1868 the permanent asylum finally opened, containing 38 patients by the end of that month (MNHL, B467/3a, 1868).

Analysis of the 1871 Census (Table 1) indicates continuing differences between the three Islands, although all now possessed public lunatic asylums. Excluding the 16 predominantly imported residents of Cranbourn House, only two of whom had been born on Jersey, about $75 \%$ of the insular lunatics were in asylums in both Guernsey and Jersey. Examination of the entire 1871 Census for Jersey (PRO, RG10/5755-64) - which gives a total of 89 lunatics, rather than the official total of 86 - indicates that the 21 lunatics remaining in the community were predominantly female, and born on the island. Only 4 were male, and 17 had been born on Jersey. The Manx asylum, however, contained over 90 per cent of the insular lunatics. The absence of a poor law system in the Isle of Man is probably a key factor, with the Manx asylum taking a number of younger idiots and imbeciles in addition to the insane. In all the islands, institutionalization continued to be the last resort, as reports from the asylums confirm. On Jersey, the Superintendent complained that community attitudes towards dealing with mental illness remained largely

TABLE 1.1871 census population and asylum statistics ${ }^{\star}$

\begin{tabular}{lrrr}
\hline & Guernsey & Jersey & Isle of Man \\
\hline Total island population & 33,969 & 56,627 & 54,042 \\
Population aged $\geq 20$ years $(\mathrm{P} \geq 20)$ & 19,504 & 33,565 & 28,883 \\
\% of $\mathrm{P} \geq 20$ born locally & 66.79 & 59.42 & 80.35 \\
No. lunatics in public asylum & 29 & 51 & 77 \\
Total no. lunatics on island & 39 & 86 & 82 \\
\% of lunatics in public asylum born locally & 86.2 & 73.4 & 88.3 \\
Non-lunatics in public asylum aged $\geq 20$ & 0 & 4 & 26 \\
Lunatics per 1000 population $\geq$ age 20: & & & \\
$\quad$ in public asylum & 1.4 & 1.5 & 2.7 \\
$\quad$ in total & 2.0 & 2.6 & 2.8 \\
\hline
\end{tabular}

* Compiled from: PRO, RG10/5760; RG10/5765; RG10/5777; BPP, 1873. 
unchanged, so 'the same lament is to be repeated year after year that the Asylum is too seldom looked upon as a Hospital and that more patients are not sent to the Asylum in the early stages of their mental disorder' (JA, Jersey Asylum, 1877). On the Isle of Man also, though the results might have been distorted by the relatively recent opening of the asylum, early annual reports indicate years without treatment:

Unfortunately there are still several who, from many years of confinement and restraint, are totally unable to be employed; in many instances their limbs having become wasted, contracted and useless. These cases are sad examples of the inroads made by insanity when allowed to proceed unchecked by proper treatment, the disorder becoming permanently established and incurable.

Other references to 'the extreme debility and advanced age of many of the inmates', with a consequential high rate of mortality, also indicate a reluctance to send cases to the asylum unless absolutely necessary (MNHL, B467/3a, 1868). Even in 1877 the Annual Report recorded the admission of two patients aged over 80 , and six more aged 70 or more, commenting that the death rate was increased through patients admitted in the last stages of exhaustion (MNHL, B467/3a, 1877).

\section{Conclusions}

The evidence presented suggests that the Home Office and Commissioners in Lunacy were initially reactive rather than proactive in their approach to the problems of lunacy in the Dependent Territories, an administrative trait of the Commissioners that has been noted elsewhere (Bartlett, 1999; Hervey, 1987). They intervened only when petitioned directly by private individuals, or when Lieutenant Governors raised issues. Only in the later 1850s did the British government become more insistent on the provision of public asylums in the islands. This reactivity is confirmed by the asylum on Guernsey which, by curtailing complaints from Lieutenant Governors and members of the public about the plight of lunatics in the community, also produced indifference by the British government as to the state of the insane on the island. In the early 1860 s the Commissioners claimed ignorance whether 'any measures whatever have been taken in Guernsey, ... with a view to affording protection to their Insane inhabitants' (BPP, 1862).

Native advocates of the public asylum were relatively rare, even among the medical profession. The strongest supporters, such as Deemster [Judge] Drinkwater in the Isle of Man and D. H. van Leeuwen in Jersey were usually members of the Lieutenant Governor's circle or incomers. Thus the Lieutenant Governors, as local representatives of the British government, played an important role. In the Isle of Man, most of the Lieutenant Governors involved during the period were long-serving and politically experienced, 
able to work with the House of Keys and accept the limits of the immediately possible (Winterbottom, 1999). In Jersey they were invariably former military personnel who generally served shorter terms of office of five years or less. A change of Lieutenant Governor could alter the progress of the discourse; when in August 1860 Sir Percy Douglas replaced Major General Mundy (who had considered the Curateurial system an attractive feature of the laws of Jersey; JA, A/A1/10, 1858), policy became both more proactive and less sympathetic to local traditions.

The autonomous legal status, differing political structures and relatively small population of the islands and differing traditions of social welfare led to challenges to the public institutional model from a subscription model, and from an entrepreneurial proprietor of a private madhouse, attracted by the lack of effective supervision and regulation. More generally, public asylums were challenged by those who thought the plans catered for too large a number, or at too extravagant a cost. The relatively small size of the island institutions compared with the mainland meant that they were closer to the ideal size for 'moral treatment'. However, the capital costs of buildings not only for the accommodation of the patients, but also for their spiritual care (though in the case of the Isle of Man, this was initially dispensed with) and other ancillary activities, and accommodation for senior staff such as resident medical officer and matron (see Taylor, 1991), were distributed among fewer inmates, as were the ongoing salary and running costs, meaning that an insular asylum could prove expensive on a per capita basis. These issues could be problematic, particularly when, in both Jersey and the Isle of Man, the debate became subsumed in more general political issues concerning the financial relationship with the British government and the limits to the political powers of the insular governments.

\section{Acknowledgements}

The research on which this article was based was funded by the Wellcome Trust (grant 076164). The author would like to thank an anonymous referee for his comments, and the staff of the States of Guernsey Island Archives Service, Jersey Archives Service, Société Jersiaise, Manx National Heritage Library and the Houghton Library (University of Harvard), for their assistance. Material from the Dorothea Dix Collection is reproduced by permission of the Houghton Library, University of Harvard.

\section{References}

\section{(a) Archive sources}

(The following abbreviations are used: HO Home Office; LG Lieutenant Governor)

Houghton Library [HL], Harvard University, Cambridge, MA 02138, USA bMS Am 1838 Dorothea Dix Collection: 
(1855) (a) Letter, van Leeuwen to Daniel Hack Tuke, 8 May; (b) Letter, van Leeuwen to Dix, 14 June; (c) Letter, Sir George Grey to Dix, 28 June; (d) Letter, van Leeuwen to Samuel Gaskell, 2 July; (e) Letter, van Leeuwen to Dix ["July" written in different hand, but probably later - Nov.?].

\section{Jersey Archives Service [JA], Clarence Road, St Helier, Jersey JE2 4WH}

[ACTES] St Saviour's Hospital Acts des Etats et autres documents sur la Fondation, la Construction et l'Organisation d'un Asile d'Alienes à fersey [uncatalogued]:

(1846) (a) Letter to Dr Bowring, MP, 22 Nov.; (b) Letter, Royston to LG, 16 Dec.; (c) Statement by John Cutts, undated [1846]; (d) Letter, Bailiff to LG, 21 Dec.

(1847) Report by Drs Sharkey and Brohier, 28 Jan.

(1852) Hospital Committee, Minutes, 27 Dec.

(1853) Reports by Drs De Caux and Van Leeuwen, 20 Sept.

(1855) Hospital Committee Report on Lunatics, 19 Sept.

(1858) Petition from Pothecary, 28 June.

(1860) (a) Law Regulating Asylums, 4 Apr.; (b) Letter from Pothecary, Asylum Regulation Committee, 25 Sept.; (c) Minutes, Asylum Regulation Committee, 29 Sept.; (d) Letter from Pothecary, 13 Dec.

(1861) (a) Letter, LG to Lieut. Bailiff, 29 July; (b) Letter, LG to HO, 3 Aug.

(1862) (a) Order in Council; (b) Letter, Phillip Le Gallais, President, Asylum Committee, to Receiver General of Jersey, 17 Dec.

(1863) (a) Minutes, Asylum Committee, 11 May; (b) Report by Dr Boyd, 23 Sept.

A/A1/10 Governor's Letter Book of correspondence, 30 July 1857 - 1 Oct. 1860:

(1857) $\mathrm{HO}$ enclosing letter from Blampied, 1 May.

(1858) Letter from LG about Blampied, 19 Jan.

A/A1/11 Governor's Letter Book of correspondence, 18 Sept. 1860 - 20 Dec. 1865:

(1861) LG to HO, 20 May.

A/J/7 Printed Copy of Privy Council Plea:

(1839) Letter from Hon. Fox Maule, 7 Oct.

(1847) Hospital Committee reasons, 11 May.

(1859) Minutes, Asylum Committee, 4 Apr.

(1860) (a) Acts States of Jersey, 2 Aug.; (b) States Resolution, 14 Aug.

(1861) (a) Minutes, Committee on Site for Asylum, 15 Jan.; (b) Motion by Godfray, 4 Mar.

(1862) Report by Committee of States on 'Negative Voice of LG', 5 Mar.

C/A5/3 States Assembly - Official Correspondence:

(1839) (a) Governor's Office to States 10 Oct.; (b) Minutes of the States Assembly on sending lunatics abroad and lunatics in the General Hospital, 1839.

(1861) LG to States, 15 Mar.

C/C/W2/1 Committee for Supervision of Lunatic Asylums, Minute Book, 25 Sept.1860 - 26

Feb. 1906:

(1866) Minutes, 8 Feb.

(1880) Minutes, 30 Jan.

D/Y/F3/49 Judicial Greffe Register of décrets Livre 45:

(1865) 11 Nov.

Jersey Asylum Annual Reports:

(1869) First Annual Report for the Year ending 31 December 1869, p. 11.

(1877) Eighth Annual Report for the Year ending 31 December 1877, p. 9. 
Manx National Heritage Library [MNHL] Douglas, Isle of Man, IM1 3LY

MSS - Bridge House Collection:

4133C Printed appeal from Lieutenant Governor, 12 Apr. 1851.

4139C LG says $£ 1100$ raised in subscriptions.

4142C Letter from Thomas Clucas, Ballafreer, 4 Sept. 1851.

4146C Letter from Ellen Stowell, 26 May 1852.

4151/1C Letter from Bishop of Sodor and Man, 16 Apr. 1852.

4151/2C Proposal to sell Rushen, 29 Apr. 185[2?].

4153C Letter on proposed use of Rushen Abbey, 8 Apr. 1852.

4155C Letter reports no subscriptions from Kirk Bride, 24 Sept. 1851.

9845/1/4 Governors Letter Book, 11 Dec. 1832 - 11 July 1845: (1845) ff.552-3, 28 Apr. 9845/1/5 Governors Letter Book, 27 Sept. 1845 - 11 June 1849:

(1847) (a) HO to LG, f.296, 27 Feb.; (b) LG to HO, f.346, 20 Apr.; (c) HO to LG, f.437, 2 Dec.; (d) Attorney General, Isle of Man, to LG, f.438, 11 Dec.

9845/1/6 Governors Letter Book 11 June 1849 - 25 Nov. 1853:

(1850) (a) LG to HO, ff.148-50, 9 Oct.; (b) HO to LG, ff.152-3, 25 Oct.; (c) LG to HO, ff.156-60, 8 Nov.; (d) HO to LG, ff.165-6, 28 Nov.

9845/1/8 Governors Letter Book 1 Jan. 1857 - 29 Dec. 1859:

(1858) (a) LG to HO, ff.358-65, 16 July; (b) HO to LG, f.369, 23 July; (c) Letter from Edward Condery, ff.400-1, 1 Sept.

9845/1/9 Governors Letter Book, 2 Jan. 1860 - 12 Oct. 1863:

(1861) (a) LG to HO, f.315, 6 Aug.; (b) Copy letter from Dr Wilson, Liverpool, to Commissioners in Lunacy, ff.339-41, 3 Oct.

9845/1/10 Governors Letter Book, 14 Oct. 1863 - 11 Mar. 1865:

(1863) (a) Attorney General, Isle of Man, to LG, f.19, [Nov.]; (b) LG to HO, ff.85-8, 22 Dec.

(1864) (a) LG re: Asylum plans, ff.417-19, 29 Aug.; (b) Notice re: temporary Asylum, f.457, 21 Oct.

B467/3a Asylum Board Reports 1868-1879:

(1868) year ending 30 June 1868.

(1877) year ending 30 June 1877.

GO61/19 List of lunatics in the temporary asylum, 3 Jan. 1865.

GO61/23 Letter to LG re: Castle Rushen, 7 Jan. 1864.

GO61/40 LG to High Bailiffs and Captains of Parishes, 11 July 1863.

GO61/57 Reference to possible use of 'herring houses' as temporary asylum, 15 Feb. 1864.

GO61/60 Re: petition from opponents of asylum, 28 June 1864.

GO61/100 Parish responses to GO61/40, various dates 1863-64.

\section{Public Record Office [PRO], Kew, Richmond, Surrey TW9 4DU}

HO45/6397:

(1857) (a) Letter from Attorney General, Jersey, 12 May; (b) LG to HO, 30 May.

(1859) Copy letter from Commissioners in Lunacy, 21 Feb.

HO45/6570: (1864) Petition of Joseph Everard, 23 Jan.

$\mathrm{HO} 45 / 7130$ :

(1859) Letter, Commissioners in Lunacy, 19 Apr., to President [Nicholle] of the [Hospital] Committee of the States.

(1862) Letter LG to HO, 30 Mar.

(1863) Letter from UK Treasury, 8 Dec. 
MH50/7 Commissioners in Lunacy, Minutes, 30 Mar. 1854 - 15 Aug. 1855:

(1854) (a) 22 June; (b) 30 Nov.

(1855) (a) 23 May; (b) 31 May.

PC8/22 File on Privy Council case: (1862) Letter from LG, 5 Apr.

RG10/5755-64 1871 Census, Jersey.

RG10/5760 1871 Census, Jersey Asylum.

RG10/5765 1871 Census, Hospital of St Peter Port, Guernsey.

RG10/5777 1871 Census Ballamona Lunatic Asylum, Isle of Man.

\section{(b) Publications}

Anonymous (1861) [untitled] British Press and Fersey Times (14 Nov.).

Balleine, G. R. (1948) A Biographical Dictionary of fersey (London \& New York: Staples Press).

Bartlett, P. (1999) The Poor Law of Lunacy: The Administration of Pauper Lunatics in MidNineteenth Century England (London: Leicester University Press).

Belchem, J. (ed.) (2000) A New History of the Isle of Man.Vol. 5:The Modern Period, 1830-1999 (Liverpool: Liverpool University Press).

British Parliamentary Papers [BPP]:

(1847) Royal Commission to Inquire into the State of Criminal Law in Channel Islands, First Report (Fersey) [865] BPP 1847/XV:101.

(1854) Eighth Annual Report of the Commissioners in Lunacy (339) BPP 1854/XXIX:1.

(1854-55) Ninth Annual Report of the Commissioners in Lunacy (240) BPP 1854-55/ XVII:553.

(1856) Tenth Annual Report of the Commissioners in Lunacy (258) BPP 1856/XVIII:495.

(1861) Report of the Commissioners Appointed to Inquire into the Civil, Municipal and Ecclesiastical Laws of the Island of Fersey, Together with the Minutes of Evidence, and Appendix [2761] BPP 1861/XXIV:1.

(1862) Sixteenth Report of the Commissioners in Lunacy (417) pp. 71-2, BPP 1862/ XXIII: 1 .

(1864) Correspondence on Question of Proposing to Parliament Vote for Half of Expense of Lunatic Asylum on Isle of Man (428) BPP 1864/LII:259.

(1873) Census of England and Wales, 1871, vol. 3, Population Abstracts; Age, Civil Condition, Occupations and Birth-Places [872] BPP 1873/LXXI. Pt.1:1.

Carey, W. W. (1938) The History of the Careys of Guernsey (London: J. M. Dent).

Croad, G. W. (1981) A fersey Album (St Brelades: privately published).

Digby, A. (1985) Madness, Morality and Medicine: A Study of the York Retreat, 1796-1914 (Cambridge: Cambridge University Press).

Gollaher, D. (1993) Voice for the Mad: The Life of Dorothea Dix (New York: Free Press).

Goodway, D. (2004) Harney, (George) Julian (1817-1897). In Oxford Dictionary of National Biography (Oxford: Oxford University Press), Vol. 25: 354-5.

Hervey, N. (1987) The Lunacy Commission 1845-60, with special reference to the implementation of policy in Kent and Surrey. Unpublished $\mathrm{PhD}$ thesis, University of Bristol.

Hirst, D. (2005) 'A ticklish sort of affair': Charles Mott, Haydock Lodge and the economics of asylumdom. History of Psychiatry, 16, 311-32.

Fersey Independent [FI] (1861): (a) 27 July; (b) 3 Aug.; (c) 14 Oct.; (d) 17 Oct.; (e) 29 Oct.; (f) 6 Nov.; (g) 11 Nov.; (h) 15 Nov.; (i) 10 Dec.

Kelleher, J. D. (1991) The rural community in nineteenth century Jersey. Unpublished PhD thesis, University of Warwick. 
Kermode, D. G. (2001) Offshore Island Politics: The Constitutional and Political Development of the Isle of Man in the Twentieth Century (Liverpool: Liverpool University Press).

Lenfestey, G. M. (1992) Medical practices at the town hospital, 1743-1850. Report and Transactions of the Société Guernesiaise, 23, 378-472.

Moore, E. F. (1867) Reports of Cases heard and determined (1836-61) by the fudicial Committee and the Lords of Her Majesty's Most Honourable Privy Council, 15 vols (London: W. T. Clarke).

Mona's Herald and Farghar's Isle of Man Advertiser [MH]:

(1851) 30 Apr.

(1855) (a) 23 May; (b) 6 June.

(1862) 20 Aug.

(1863) 4 Nov.

(1864) (a) 10 Feb.; (b) 17 Feb.; (c) 8 June; (d) 27 July; (e) 17 Aug.

(1865) (a) 12 Apr.; (b) 12 July.

Parliamentary Debates, 3rd series (London: Hansard):

(1864) 175, 30 May, cols 861-3.

(1865) 179, 19 May, cols. 596-601.

Parry-Jones, W. L. (1972) The Trade in Lunacy: A Study of Private Madhouses in England in the Eighteenth and Nineteenth Centuries (London: Routledge \& Kegan Paul).

Stansky, P. (ed.) (1973) The Victorian Revolution: Government and Society in Victoria's Britain (New York: New Viewpoints).

Statutes of the Isle of Man (1883) Vol. 2: 1824-59; Vol. 3: 1860-71 (London \& Douglas: Eyre \& Spottiswood; Brown \& Sons).

Taylor, J. R. B. (1991) Hospital and Asylum Architecture in England 1840-1914 (London and New York: Mansell).

The Times:

(1854) 13 Dec., p. 10, col. f.

(1856) 10 Oct., p. 9, col. a.

(1864) 8 Feb., p. 9, col. d; 11 Feb., p. 6, col. c.

van Leeuwen, D. H. (1853) Rapport sur la fondation etc. des meilleurs asiles d'alienes en France (Jersey: States of Jersey).

Wilson, D. C. (1975) Stranger and Traveler: The Story of Dorothea Dix, American Reformer (Boston \& Toronto: Little, Brown \& Co.).

Winterbottom, D. (1999) Governors of the Isle of Man since 1765 (Douglas: Manx Heritage Foundation). 